\title{
When is it best to test? Attitudes of health professionals regarding genetic testing for Familial Adenomatous Polyposis (FAP)
}

\author{
E Lynch $^{1 *}$, RE Duncan ${ }^{2,3}$, F Macrae $^{4}$, M Delatycki $^{1,2}$
}

From Familial Aspects of Cancer 2011 Research and Practice: A combined meeting of kConFab, Australian Breast Cancer Family Study, Australian Colorectal Cancer Family Study, Australian Ovarian Cancer Study, Family Cancer Clinics of Australia and New Zealand and kConFab

Kingscliff, Australia. 23-26 August 2011

Familial Adenomatous Polyposis (FAP) is a well described autosomal dominant syndrome, whereby individuals develop multiple (up to thousands) of adenomatous polyps in the large bowel, conferring an extremely high risk of bowel cancer if left untreated.

If the family specific mutation is known, genetic testing can be offered to at risk individuals to determine the need for endoscopic surveillance. Guidelines suggest starting endoscopic surveillance from the early teens. Most individuals with FAP undergo colectomy between the ages of 15 and 25 years [1].

Recent studies have shown that many adults with FAP want their children to undergo genetic testing before the age of 12 years, the approximate age at which genetic testing is usually offered in Australia [2,3].

Health professionals working in cancer genetics in Australia and New Zealand completed a web based survey aimed at examining their attitudes and experiences regarding genetic testing for young people at risk of FAP.

Findings from the survey provide an insight into the views and practices of health professionals working in this area, including: the age at which they believe testing young people is most appropriate; their experiences regarding parental requests for testing of younger children; and whether the option of prenatal testing and preimplantation genetic diagnosis is routinely discussed with individuals who have FAP and are also of child bearing age. These have important implications for clinical practice within the Australian cancer genetics community.

${ }^{1}$ Austin Health Clinical Genetics Service, Australia

Full list of author information is available at the end of the article

\section{Author details}

${ }^{1}$ Austin Health Clinical Genetics Service, Australia. ${ }^{2}$ Bruce Lefroy Centre for Genetic Health Research, Murdoch Childrens Research Institute, Australia.

${ }^{3}$ Centre for Adolescent Health, Children's Bioethics Centre, Murdoch Childrens Research Institute, Australia. ${ }^{4}$ Department of Colorectal Medicine and Genetics, The Royal Melbourne Hospital, Australia.

\section{Published: 12 April 2012}

\section{References}

1. Vasen, et al: Guidelines for the clinical management of familial adenomatous polyposis (FAP). Gut 2008, 57:704-713.

2. Douma KF, et al: Attitudes toward genetic testing in childhood and reproductive decision-making for familial adenomatous polyposis. Eur $J$ Hum Genet 2010, 18:186-193.

3. Andrews, et al: Impact of familial adenomatous polyposis on young adults: attitudes toward genetic testing, support and information needs. Genet Med 2006, 8:697-703.

\section{doi:10.1186/1897-4287-10-S2-A43}

Cite this article as: Lynch et al:: When is it best to test? Attitudes of health professionals regarding genetic testing for Familial Adenomatous Polyposis (FAP). Hereditary Cancer in Clinical Practice 2012 10(Suppl 2):A43.

\section{Submit your next manuscript to BioMed Central} and take full advantage of:

- Convenient online submission

- Thorough peer review

- No space constraints or color figure charges

- Immediate publication on acceptance

- Inclusion in PubMed, CAS, Scopus and Google Scholar

- Research which is freely available for redistribution 